\title{
LAND GRABBING AND GLOBAL GOVERNANCE: CRITICAL PERSPECTIVES
}

\author{
Matias E. Margulis* \\ Division of History and Politics \\ University of Stirling \\ Email: m.e.margulis@stir.ac.uk \\ Nora McKeon \\ Independent Researcher, Rome, Italy \\ Saturnino M. Borras, Jr. \\ International Institute of Social Studies
}

\begin{abstract}
Land grabbing has emerged as a significant issue in contemporary global governance that cuts across the fields of development, investment, food security, among others. Whereas land grabbing per se is not a new phenomenon, having historical precedents in the eras of imperialism, the character, scale, pace, orientation and key drivers of the recent wave of land grabs is a distinct historical phenomenon closely tied to major shifts in power and production in the global political economy. Land grabbing is facilitated by ever greater flows of capital, goods, and ideas across borders, and these flows occur through axes of power that are far more polycentric than the North-South imperialist tradition. In this introduction we argue that land grabbing speaks to many of the core questions of globalization studies. However, we note scholars of globalization have yet to deeply engage with this new field. We situate land grabbing in an era of advanced capitalism, multiple global crises and the role of new configurations of power and resistance in global governance institutions. The essays in this collection contribute to identifying land grabbing as an important and urgent topic for theoretical and empirical investigations to deepen our understanding of contemporary globalization and governance.
\end{abstract}

Keywords: land grabbing, large-scale land acquisitions, globalization, global governance, polycentrism

*This is an Accepted Manuscript of an article published in Globalizations 10(1): 1-23 (2013), available at: http://www.tandfonline.com/doi/full/10.1080/14747731.2013.764151

Doi: 10.1080/14747731.2013.764151 


\section{Introduction}

Over the last few years, land grabbing has become a well-established phenomenon. There are varying estimates of the quantity of lands that have changed hands during recent years, from a low 45 million hectares (World Bank, 2010) to a high 227 million hectares (Oxfam, 2012), although how the counting was done in these estimates is not always clear. This global land rush is characterized by transnational and domestic corporate investors, governments and local elites taking control over large quantities of land (and its minerals and water) to produce food, feed, biofuel and other industrial commodities for the international or domestic markets. Such land deals are very often associated with very low levels of transparency, consultation and respect for the rights of local communities living off the land (Borras and Franco, 2010; Cotula, 2012; Zoomers, 2010). In response to concerns over the real and massive experiences of dispossession, violence and social exclusion, land grabbing has been elevated to an issue of world political significance around which local and transnational resistance has swelled and for which new global governance instruments are being created. The importance of land grabbing as a topic in global governance is well established. This salience is confirmed by events in the real world: land grabbing is on the agenda of the Group of Eight (G-8)/Group of Twenty (G-20); it is at the core of the World Bank's new global development agenda; several new global governance instruments have been negotiated to address land grabbing; global civil society and transnational social movements are mobilizing around this phenomenon; and investors and corporations are intensifying their acquisitions and global competition for land.

The idea of a land grab has a long intellectual history dating back to the writings of Karl Marx. The study of land and agrarian change has been integral to our understanding of the development of capitalism and the contemporary world order (Peluso and Lund, 2011; Arighi and Karides, 2012). We recognize that land grabs today are deeply shaped by past practices and historical legacies and exhibit continuities from the past but also diverge in significant ways, and are riddled with contradictions and tensions. Our emphasis here, however, is on the specific contemporary context that is giving rise to land grabbing on a global scale. There is a burgeoning academic literature that has so far examined land grabbing from the perspective of agrarian political economy (White et al., 2012, Peluso and Lund, 2011) and political ecology (Fairhead, Leach \& Scoones, 2012), as well as around the issues of food security (Robertson \& Pinstrup-Anderson, 2010), food sovereignty (Rosset, 2011), labour (Li, 2011), human rights (De Schutter, 2011), gender relations (Chu, 2011; Berhman, Meinzen-Dick and Quisumbing, 2012; Julia and White 2012), land use change (Friis \& Reenberg, 2010), the role of the state (Wolford et al., 2013), water grabbing (Mehta et al., 2012, Allen et al., 2012), and neoliberalism (Araghi and Karides, 2012).

With some exceptions scholars of globalization in general have been absent from the debate on this emerging issue. This is unfortunate because land grabbing is emblematic of contemporary globalization and speaks to many of the big questions that concern scholars of globalization. Land grabbing is facilitated by ever more extensive and rapid flows of capital, goods, and ideas across borders and these flows occur through axes of power that are far more polycentric than the North-South imperialist tradition. In addition, land grabbing is occurring in the context of late capitalism and a global multiple food-energy-climate-finance crises in which we can see the changing character of global production and consumption, including an integrated global food-energy complex. Land grabbing is a global-scale phenomenon that is occurring in all regions and parts of the world, and not only in Africa as is assumed to be the case (see Visser and Spoor, 2011, on post-Soviet Eurasia; Borras et al., 2013), on Latin America; Borras and Franco, 2011 on Southeast Asia). Whereas land grabbing per se is not a new phenomenon, having historical precedents in the eras of colonialism and imperialism (Alden-Wily 2012), 
the drivers, scale, and pace of the recent wave of land grabs are distinct from previous eras. As Saskia Sassen, explains (2013, this volume), unlike in the eras of colonialism and imperialism the current wave of land grabs occurs in a world of sovereign states exercising territorial control at least formally. Transborder flows of capital, property rights, and agricultural production go through, rather than bypass, multiple layers of formal governance mechanisms ranging from investment and trade treaties to financial markets. Therefore, contemporary global land grabbing displays properties specific to our era of advanced economic globalization. Land grabbing is an important site of new transnational political struggles for authority and control over resources and governance. These struggles go beyond who should control the land, and are contests largely about what should be grown on it, how, by whom, for what markets, hence the future of global agriculture. Thus the stakes being fought over in the struggles for global land grab are massive and are likely to reshape the future course of globalization, partly by producing openings and/or closing off avenues for global policies and practices that provide those that live off the land with autonomy, including a degree of protection from global economic forces, to decide future life courses.

In this introductory essay, we raise the point of the need for globalization studies to address more systematically the issue of global land grabbing. As suggested above, the global land grab reveals strongly many aspects of economic globalization. In the same instance, contemporary globalization cannot be fully understood without a deeper understanding of land grabbing. It is useful to develop a more nuanced understanding of new and important sets of transborder flows, power relations, and political struggles that converge where land grabbing occurs and in global-scale governance institutions and practices. These global aspects have remained largely under-studied and under-theorized but are precisely the terrain for inquiry where globalization scholars are most strongly situated to engage with questions concerning territory, power, authority, and resistance.

This collection is a preliminary effort seeking to bring a lens from globalizations studies to land grabbing. Our purpose is twofold. One is to offer initial analyses of land grabbing from a globalization perspective in order to bring land grabbing to the attention of scholars interested in globalization and transnational governance. Our hunch is that given that land grabbing cuts across so many core areas of globalization research - territorialisation, financialization, trade, human rights, crises, and so on readers will quickly start to see the links between their work and the ideas presented here and in the process we hope to stimulate new questions and lines of investigation in the field. A second purpose is to foster greater dialogue between scholars of globalization with the burgeoning literature on land grabbing spearheaded by the agrarian political economy and political ecology scholars. These latter fields of study, which now provide an extensive set of case studies of land grabbing, would be enriched by the global-scale theoretical contributions of globalization and transnational governance studies. This can lead to more robust analysis of global-local interactions behind land grabbing. One starting point for such cross-fertilization is to consider how local land struggles are likely to be altered by changes in the global policy environment, such as the entrance of foreign investors that is permitted by the burden of debt regime affecting most developing countries - as Sassen (2013, this volume) explains, but also by global governance instruments aimed at defending the rights of those who live off the land (2013 McKeon, 2013, this volume; Kunnemann and Monsalve Suárez, 2013, this volume). Studies of globalization and governance also stand to benefit from a deeper engagement with agrarian political economy and political ecology analysis of land grabbing because the latter have produced deep knowledge of the social, economic and political effects of the multiple food-energy-climate-finance crises on the ground. Globalization and transnational governance scholars have disproportionately paid attention to the recent global financial crisis with little consideration of the other related political economy processes. It is not our point that one crisis (i.e., financial, food or climatic) is more important 
than another one. Instead our point is that knowledge of globalization in the $21^{\text {st }}$ century is most likely to be enhanced only when we start from the standpoint that these crises are mutually affected world historical events.

This collection is organized around the transnational contestation of land grabbing and its governance. This is because the global/transnational scales are sites of new and significant governance activity. This volume offers a perspective that examines land grabbing and its governance as embedded within a larger international political economy context. The collection offers critical perspective in the sense of that most authors in this collection are concerned by land grabbing and its negative social and ecological consequences. Hence, this collection is sympathetic to a global social justice agenda. It is in this context that we also purposely include knowledge and experiences from outside the academy: several of the essays in this volume are written by activists situated in global civil society that have participated in the negotiation and resistance politics of emergent global land governance. This coming together of academic and activist researchers enriches this collection immensely, and is important for co-production and -mobilization of knowledge.

\section{Global Governance and Land Grabbing}

One of the notable developments that followed public awareness of a global land grab in 2008 was the rapid elevation of land grabbing onto the global governance agenda and a flurry of global rule-making projects at various scales involving a multiplicity of actors to regulate land grabbing. Land grabbing has been taken up in the work of the United Nations (UN) system and Bretton Woods institutions - but most actively at the UN Food and Agriculture Organizations (FAO), the Committee on World Food Security (CFS) and the World Bank, at the G8 and G20 summits, at the European Commission (i.e., in discussion about the indirect effects of its biofuel mandate), and at African Union's work on a regional land policy framework. The well known, flagship global rule-making projects are the recently negotiated UN Voluntary Guidelines on the Responsible Governance of Tenure of Land, Fisheries and Forests (herein 'Voluntary Guidelines', see Seufert, 2013, this volume) and the ongoing transnational negations to develop rules for responsible agricultural investment (see Stephens, 2013, this volume). Many other projects have been spawned by the food crisis that impact on global governance and are directly related to land grabbing, such as the Global Agriculture and Food Security Program (a new multi-donor trust fund that encourages public and private investment in agriculture), the G8's so-called New Alliance for Food Security and Nutrition, a development assistance program now spearheaded by the Obama administration, and the World Economic Forum's “Grow Africa” initiative. All of these projects share the objective of promoting large-scale private-sector led investments in developing country agriculture and highlighting the weight of investments relative to that of policies. Meanwhile, dozens of countries are revisiting and reforming national and local land planning and tenure laws as well as their bilateral/multilateral trade, investment and development cooperation arrangements - and depending on the local politics, doing so to either facilitate (Wolford et al., 2013) or limit (Perrone, 2013, this volume; Murmis and Murmis, 2012; Wilkinson et al. 2012) land grabbing domestically.

'Global governance' is a term that is widely used to refer to the modern practice of governing transborder problems and to the institutions, rules, actors, and ideologies that govern the global political economy (we include here the social and biophysical). Global governance as an academic concept and field emerged in the 1990s in response to new global-scale problems such as HIV/AIDs, climate change and international migration that came to be understood as beyond the capacity of any single nation-states to manage on their own (Roseneau, 1995). The field of global governance was also deeply influenced by 
shifting power at the global level and its implication for international cooperation; this included at first the fall of Soviet Union and what this meant for US unipolarity and multilateralism and, more recently, the focus on emerging countries as new players in multilateralism. Today the term global governance is widely used by academics and the general public in in a variety of always and meanings, including reference to the 'practices of governance without government' (Roseneau and Czempiel, 1992); a 'normative goal' (Wiess, 2000); a 'discourse' (Brand, 2006); the inclusion of actors other than nation states (McKeon, 2009) and the 'institutionalization of the neoliberal globalization project' (Cox, 1993). Like other scholars, we recognize the complexity and contradictions bound up with this term/concept and empirical reality (see Wilkinson and Hughes, 2002; Kahler and Lake, 2003). In our view, a critical approach to global governance is required to make sense of the new global rule-making projects around land grabbing. This includes identifying the actors, interests and ideologies driving particular governance initiatives but also the international political economy context in which such initiatives arise.

\section{Land and Territoriality}

Land at first glance does not easily fit the type of singular issue-areas commonly associated with contemporary global governance. Unlike other fields of global governance such as climate change, HIV/AIDs, and terrorism that are framed as global-scale problems that are broadly recognizable as such by the global imagination - climate change with (negative) ecological change, HIV/AIDs with high mortality rates, terrorism with unpredictable violence - land does not slot easily into existing socially constructed categories of a global-scale "problem”. Unlike earlier moments of world history the contemporary period of world order is one defined by nation-states as the primary forms of political organization. As such, in the current era land and its control have tended to be equated with state practices. This conception of land as integral to sovereign territory and authority is affirmed by most international practices, such as international legal recognition of state borders and territorial authority (i.e., the spatial demarcation of where a state's land and water borders begin and end). In the postcolonial era, land is regarded as a thing belonging to a national state. In general, land has not figured as a significant issue-area of global governance with the exceptions of instances of where land is invaded by an occupying force. Land as sovereign territory is a key international norm and framework critical to understanding the politics of global land governance. This particular norm and discourse that the land belongs to the state is especially strong in post-colonial states where the state owns most of the land. Rolf Kunnemann and Sofía Monsalve Suárez (2013, this volume) note that land tenure governance regimes in the Global South mirror their colonial antecedents in that they provide the state with far reaching control over the land. They contend that while contemporary land grabbing may be driven by global economic actors, the importance of national legal frameworks should not be overlooked because these have actually made it easier for states to facilitate land grabbing. Closely related to the argument made by Kunnemann and Monsalve Suárez, Borras, Franco and Wang (2013, this volume) explain that states actively facilitate land grabs through a combination of the following tasks that only national governments have absolute authority to perform, namely, (i) ‘invention/justification' of the need for large-scale land investments, (ii) 'definition, reclassification and quantification' of what is 'marginal, under-utilized and empty’ lands; (iii) ‘identification’ of these particular types of land; (iv)

'acquisition/appropriation' of these lands, and (v) 're-allocation/disposition' of these lands to investors. Much of what is being grabbed is within the legal-administrative-military control of national states.

The global land grab raises deeper questions about territoriality in the era of advanced economic globalization. In her contribution to this collection, Saskia Sassen (2013, this volume) explains that the global land grab suggests a larger structural transformation at play that is " producing massive structural holes in the tissue of national sovereign territory”. For Sassen, the global land grab reveals an "active making of an increasingly large number of partial, often highly specialized, cross-border spaces and 
arrangements” occurring during a moment of massive systematic change; land is shifting from sovereign national territory to a commodity for the global market. Land is highly demanded by capitalism that is leading to the rapid commodification and financialization of land on a world scale and "re-purposing" of national territory along the lines of the demands and purposes of foreign firms and governments (Sassen, 2013, this volume). This, according to Sassen, does not signal the end of the state but a transformation of the state that is ever more inserting itself into transnational processes that operate according to other (non-national) logics. However, such transformation can be highly destructive to society and citizenship: "Foreign land acquisitions include vast stretches of national territory articulated through villages, smallholder agriculture, rural manufacturing districts, and through the actors that make these economies and reproduce them -whether this is or not recognized by the state. Much of this political-structural complexity is today being evicted from that territory due to those acquisitions. At the extreme we might ask "what is citizenship when national territory is downgraded to foreign-owned land for plantations and the rest is evicted - floras, faunas, villages, smallholders” (Sassen, 2013, this volume).

In his contribution to this collection, Philip McMichael's (2013, this volume) reading of the global land grab through a 'food regime' lens similarly identifies the global grab as a paradox, where "'reterritorialization' via investment in offshore lands for agro-exporting of food, fuel and bio-economic products, and 'de-territorialization' as host states surrender land and water for export to states defined (through market measures or policy) as food-dependent”. Indeed, the global land grab signals a major shift in the global agri-food system because the process of 're-territorialization' is a strategy by certain states and investors "to avoid dependence on markets, or more particularly, market intermediaries" that he labels as an incipient form of 'security mercantilism' that is overriding the World Trade Organization (WTO)/corporate food regime with a set of bilateral arrangements organized by states and/or sovereign wealth funds (McMichael, 2013, this volume).

A Short History of Global Land Governance and Structural Changes in the Global Political Economy The current efforts to construct land grabbing as a sphere of global governance need to be put in the historical context of global land politics. The post-war interstate system dominated by the United States (US) actively sought to keep the land question out of formal international governance institutions and practices. This was largely a response to quash leftist and socialist states that sought to create international instruments to reinforce land reform and/or collectivization at home. Land reform, especially the nationalization of privately held lands and land redistribution from elites to peasants/landless poor, has long been a highly ideological and politicized struggle. Land reform was a very contentious issue of international significance during the Cold War. In the 1960s, under the Alliance for Progress, the US supported land reform on a selective basis; providing bilateral assistance to countries where it regarded land reform, if not adequately addressed, would result in communist revolutions. An early effort to establish formal international governance for land took place at the World Conference on Agrarian Reform and Rural Development (WCARRD) convened by FAO in 1979. The aim of this conference was to establish an international framework (in the context of the Cold War) for land reform and rural development. Despite political momentum in advance of the conference WCARRD was unsuccessful in reaching this objective. As Nora McKeon (2013, this volume) explains, the international land agenda lost further steam, as it fell "victim in the "80s to the introduction of structural adjustment and a general disenchantment with agriculture as a motor for development”. Whereas land reform was pulled out of oblivion in the 1990s as part of the World Bank-led implementation of market-led agrarian reform approach, land had receded in importance for states as an issue requiring international deliberation. It is partly the lack of political progress at the international level to advance social justice-oriented redistributive land policies that eventually led to the conditions that gave birth to the 'Global Campaign for Agrarian Reform' by La Via Campesina and its allies. 
Launched in 1999 originally as an anti-market-assisted land reform campaign, the campaign later evolved into a more comprehensive agrarian reform agenda (Borras and Franco, 2009). This campaign has contributed to the revival of agrarian reform in the international official agendas, especially at the FAO. In turn, this led to what is essentially a second version of WCARRD, the International Conference on Agrarian Reform and Rural Development (ICARRD) in March 2006, organized by FAO and hosted by the Brazilian government and held in Porto Alegre.

The ICARRD initiative paved the way for states and rural social movements to articulate a new normative basis for future international land governance that included, among others, the recognition of collective land rights and acknowledged the cultural and social dimensions of land (see McKeon, 2013, this volume; McKeon 2009; ICARRD, 2006). This event was critical in that it brought land issues back on the official agenda of the FAO's deliberative bodies. Around this time, bilateral and multilateral agencies initiated and passed their own land and development policies, including the European Union (EU) in 2004, the International Food and Agricultural Development (IFAD) in 2009, the Swedish International Development Agency (SIDA) in 2009, the United Kingdom's Department for International Development (DFID) in 2010. One of the most concrete outcomes of ICARRD has been the decision by the FAO, supported by civil society organizations, to start a process for possible voluntary guidelines on land tenure. However, political consensus on negotiating international rules proved elusive and were crawling along until the global land grab (on the heels of the global food crisis) put the negotiations under the global spotlight. As the global land grab became a matter of public knowledge and concern, it provided the political impetus and sense of urgency to move forward on global land governance. The outcome of this was the negotiation and adoption in 2012 of the Voluntary Guidelines in the newly reformed CFS (which is itself an innovative experiment in global governance). Taking the long view, the global land grab proved to be a significant tipping point in the politics of land that has ushered in land governance at the global-scale.

Land grabbing also signals shifts in world order. Land grabbing already points to a transition towards new world political, economic and biophysical conditions with the emergence of the BRICs and middleincome countries, global biofuels complex, and green grabbing (McMichael, 2012). Key aspects of this shift include the geographic sites and modes of agricultural production with the Northern grain-based food regime being supplanted with "the emergence of new players wanting to gain power in terms of reshaping international rules that govern the production, distribution and consumption of food and other closely related commodities embedded within the ongoing reconfiguration of key hubs of global capital” (Borras, Franco, and Wang, 2013, this volume). These new players include the BRICS countries, powerful middle-income countries, new OECD countries such as South Korea, and the Gulf States. However, new and old powers pursue different ends through land grabbing. In his contribution to this collection Eckart Woertz drives home the point that Gulf States are quite different from the other players in contemporary land grabbing because of their unique political economy conditions. They are rentier states highly dependent on imported food and aware of the historical legacy of the failed 1970s pan-Arab breadbasket strategy that involved land grabbing in Sudan and Egypt (Woertz, 2013, this volume). This time around, and also in response to the depth of the global food crisis, Gulf States are creating new institutions to coordinate food security policies and land investments, including a mix of public and private ventures. A key but less well understood phenomenon is the importance of crops and commodities with multiple and flexible uses across food, feed and biofuel complexes and industrial commodities; much land grabbing is for what Borras, Franco and Wang (2013, this volume) call the 'flex crops and commodities' sector. A second important aspect is the shift towards a multipolarity evidenced by the replacement of the G8 with the G20 and the ascent of emerging countries in the governance architecture for finance, trade and climate change (see Margulis and Porter, 2013, this volume; 
McMichael, 2013). As Margulis and Porter argue in their essay, the global land grab cannot be reduced only to core-periphery relations. Even though Chinese activity in land acquisitions in rural Africa display "asymmetries of power and patterns of exploitation very closely resembling core-periphery relations......Chinese land acquisitions in rural Australia are not captured well by a core-periphery label” (Margulis and Porter, 2013, this volume). Indeed the same applies to grabbed-land grabbers such as Brazil and Argentina which are both major players in the land acquisitions across South America but are also major targets of foreign land acquisitions (see, Perrone, 2013, this volume; see also Borras, Kay, Gomez and Wilkinson 2012; Murmis and Murmis, 2012; Urioste 2012). To a certain extent, land grabbing reveals important shifts in global political power but also in production of resources and goods that may be more vital to a future global political economy where the ecological considerations become more paramount.

\section{Governance and Authority}

A number of concepts from global governance scholarship are relevant for the study of land grabbing. The first is the concept of authority that is closely related to the idea of governance; which actors have authority to regulate a particular sphere of activity? Global governance scholarship has shown that authority has flowed into two principal ways over the past decades in ways that differ from the post-war international system of governance.

First, there has been a shift of authority delegated from the state to international institutions. International institutions play a greater role in managing inter-state affairs than previously; this is most prominent in the case of the EU, the WTO and the International Criminal Court (ICC) that can take decisions that are binding on states and constrain a state's policy space. Emerging global land governance at first glance does not appear to involve a formal delegation of land governance from the state to supranational institutions. None of the transnational governance mechanisms - the Voluntary Guidelines or principles for responsible agriculture investment - are taking the form of legally binding international treaties. However, multilateral institutions are the key sites for the new politics of addressing land grabbing. In particular, we can observe different actors enrolling different multilateral institutions to advance alternative objectives. The G8 countries have enrolled the World Bank as their preferred site for the creation and implementation of emergent global land governance. The World Bank's official policy supports large-scale investments in lands as a means to improving agricultural productivity and economic growth that fit well within its new agricultural development strategy that has become the core of its activities since 2008. Simply put, the G8 countries have sought to provide the World Bank with the authority to be the leading agent in this new sphere of governance and they have continued to provide it with resources and entrust it to manage a spate of new global agricultural development programs. Global civil society and transnational rural movements have instead enrolled the FAO and the UN Committee on World Food Security (CFS) to serve as a key arena for emergent global land governance. The FAO and the CFS are global policy spaces that have been much more open to incorporating human rights and exploring food sovereignty as an alternative paradigm for global agricultural policy. The CFS, in particular following the 2008 global food crisis, has been reformed and has taken on a more central role in global agricultural and food policy debates (Margulis, 2013; 2012; McKeon, 2011). For many, including McKeon (2013, this volume) the CFS has filled, partially, a governance gap that existed for transnational political deliberation over food security and rural development. But, the CFS is not the only important arena in which transnational agrarian movements try to construct global governance in their favor. They engage in other strategic undertakings through multilateral institutions, such as the Human Rights Council (HRC) for Via Campesina's advocacy for a UN Peasants’ Charter (Edelman and Carwil, 2011). 
Global governance scholarship also has examined the shift of authority to non-state actors. Non-state actors have taken on governance functions in existing policy fields but also in new areas of activity. The first group includes private actors that play a greater role of governing transnational financial transactions and economic flows often through modes of self-regulation, including through the use of standards and benchmarking, as well as private international arbitration of financial and investment deals (Cutler, Haufler and Porter, 1999; Hall and Biersteker, 2002). NGOs and transnational social movements too have increased authority in global governance and this is seen in diverse areas ranging from fair trade labeling and certification to developing industry standards for humanitarian relief to the monitoring and reporting of human rights and environmental abuses (Cashore, 2002). The rise of non-state authority should not be seen as a zero-sum game where states compete with non-state actors for authority in governance. The situation is more nuanced. Many private forms of governance require explicit consent from the state, especially legal approbation of private practices at the national level and for their global operations (Brathwaite and Drahos, 2000). In practice states always retain some regulatory oversight even if they choose to exercise it lightly. There is also a trend toward hybrid forms of global governance, where even industry-led initiatives involve states and NGOs as stakeholders in governance practices and implementation along with private actors such as at the International Standards Organization (Clapp, 1998) or the Global Fund for Aids, Tuberculosis and Malaria (Hein and Kohlmorgen, 2008). Non-state actors also exert authority outside of formal global governance arrangements. For example, credit rating agencies' assessment of the state's credit worthiness (i.e., in the form of bond ratings) has a significant influence on the state's financial affairs. Transnational business lobbies also work to influence global rules such as in the creation of the intellectually property rights regime at the WTO (Sell, 2003). NGOs and transnational social movements have contested global economic governance such as mobilizing against the policies of multilateral institutions like the World Trade Organization (WTO), the World Bank and International Monetary Fund producing what O’Brien et al. (2000) identify as a 'complex multilateralism' whereby multilateral institutions seek to respond to pressure from transnational social movements and other non-state actors.

Transnational social movements and NGOs are highly visible in the politics and emerging global land governance. NGOs were the first to bring the global land grab to public attention (GRAIN, 2008). Moreover, NGOs and transnational agrarian movements were also quick to mobilize transnationally against the global land grab. However, mobilization at the global scale this time around has less to do with organizing mass public protests (as it was in the case against WTO), but tends to focus on advocacy work in global policy spaces, particularly the CFS. It has its strengths and weaknesses as a form and site of collective action (for an elaboration see Margulis, 2012). The emphasis on the CFS work (in the midst of a relative absence of anti-WTO type of mass mobilizations) is politically relevant, and we argue that NGOs and transnational agrarian movements are contributing to the creation and contesting emergent global land governance (see also Borras and Franco, 2009). McKeon points (2013, this volume) to the importance of the 'reformed' CFS as an open space that was available for transnational agrarian movements and their NGO allies, working through the International Planning Committee (IPC) for Food Sovereignty - today's largest international coalition of rural social movements - to introduce land issues as an item for intergovernmental deliberation at the CFS. According to McKeon (2013, this volume), "[c]ivil society intervention in the discussions was decisive in obtaining agreement that the Voluntary Guidelines be negotiated within the CFS..... outcomes were largely attributable to the innovative format of the CFS whereby political decisions are made in plenary sessions in which civil society and social movements are full participants rather than in closed door drafting committees as is normally the case in intergovernmental forums.” The embeddedness of global social movements at CFS provides a novel experiment in complex multilateralism (see O’Brien et al., 2000). 
The participation of global civil society is more than token inclusion; global civil society at the CFS has been relatively successful in advancing its goals and articulating alternative policies that challenge the mainstream policies advanced by the G8 and World Bank. Indeed, the success by global social movements to position the Voluntary Guidelines as a wedge and counter-discourse against the earlier maneuver of the World Bank to place the Principles for Responsible Agricultural Investments (PRAI) which is essentially a voluntary, corporate self-regulatory instrument - as the center piece to regulate land grabbing is indicative of the chessboard politics shaping emergent global land governance (McKeon, 2013, this volume; Margulis and Porter, 2013; this volume).

The heightened presence of global civil society presents its own challenges. At a deeper level is the tension within and between global civil society groups caught between the three political tendencies to governing the land grab identified by Borras, Franco and Wang (2013, this volume), namely, regulate to facilitate land deals; regulate to mitigate negative impacts and maximize opportunities, and regulate to stop and rollback land grabbing. The position global civil society actors take on this continuum results partly from ideological (i.e., taking an explicit anti-capitalist stance or not), institutional (i.e. whether an autonomous coalition of agrarian social movements or a coalition of NGOs, aid donor agencies, and international financial institutions) and differences in strategy and tactics of political work (i.e. dealing with land grabbing in focusing on the 'here and now' issues in specific land cases versus dealing with strategic issues such as the character and orientation of the world's agriculture) (Borras, Franco, and Wang, 2013, this volume). These positions are significant because they "compete with each other in their interpretations of key international governance instruments, how to use these, and for what purposes" and thus the meaning ascribed and how emergent global land governance will be implemented on the ground (ibid.).

Private sector actors concerned by emergent global land governance were relatively less present than global civil society organizations in the CFS at the outset, but they have engaged increasingly as the political salience of this forum has become more evident, in close alliance with several national governmental official delegations to the CFS process. As several authors in this collection note, it is ironic that the initial drive for private self-regulation has been most strongly advanced by the G8 countries and the World Bank but not by private actors themselves (McMichael, 2013; this volume; McKeon, 2013, this volume, Margulis and Porter, 2013, this volume). Indeed, much of the World Bankproposed Principles of Responsible Agricultural Investment (PRAI) seeks to integrate the numerous transnational private self-regulatory schemes on sustainability (Stephens, 2013, this volume; see also Borras and Franco, 2010). Fortin and Richardson (2013, this volume) argue that private certifications schemes fall short of providing the protection of land rights its champions suggest. Such schemes cannot ensure sourcing is from farmers and that free, prior, and informed consent (FPIC) respected, and could not fully account for intensified competition for land resulting from indirect-land use change (Fortin and Richardson, 2013, this volume). Fortin and Richardson suggest certification schemes enhance the scrutiny of land deals because of the information made public through auditing process and while providing some leverage to pressure large transnational firms procurement practices whose brand is closely tied to claims of 'sustainability'. Ultimately, certification schemes continue to fall short of providing robust protection of land rights and a pro-poor policy framework to support rural development and livelihoods.

There is already an alliance among the private sector (e.g., World Economic Forum, Bill and Melinda Gates Foundation), the G8 and the World Bank that cooperate in promoting global agricultural development projects. These actors remain highly supportive of promoting private standards and certification as the primarily means to address land grabbing. Even if only some private actors engage in 
the formal spaces of emergent global land governance, most can choose to operate through backdoor lobbying, aggressive media work to influence governance process, and low key negotiations especially within other global governance institutions for finance and investment, and the World Bank that are less accessible to global civil society (especially the radical elements that now participate in the CFS). In addition, agri-food corporations and large institutional investors engaged in land grabbing can resort to their structural power to advance their agendas (see Clapp and Fuchs, 2009).

\section{Land Grabbing as Struggles for Control Grabbing and Land Authority}

We now turn to a discussion about conceptualizing land grabbing. Indeed, one of the central aims of this collection is to explore different approaches to the study of the global land grab from a perspective that takes seriously insights from work on globalization and governance. At the same time, theorization and analysis can be done without complete and perfect information about land grabbing (see discussion on the politics of number below) once we begin to conceive of land grabbing as embedded in wider processes rather than just procedural matters concerning the formal transfer of property rights. Take for example Saskia Sassen's essay in this collection which argues that land grabs are particularly strong illustrations of the global inserting itself into the local revealing significant contradictions at play; states are simultaneously acting as active facilitators of land, which on the one hand is an assertion of national sovereignty, while in the very same instance they are ceding territorial sovereignty (Sassen, 2013, this volume).

For the contributors to this collections land grabbing is marked by a twofold transnational contest for control over resources and authority over institutions. Current research has demonstrated that land grabbing reveals a sharp and intensifying global competition for control over land (Peluso and Lund, 2011), including the bundle of productive resources contained in or on the land. This process manifests itself in efforts to control specific pieces of land most visible in the exchange of property rights to a specific piece of land on a permanent or temporary basis. Formal recognition of land control always includes access to a bundle of resources (i.e., water, subsoil minerals, organic and genetic matter, etc.) that may not necessarily be captured in a formalized mode but can affect others' use and access to the productive resources found in or on the land (Ribot, 2002; Ribot and Peluso, 2003; see also Sikor and Lund, 2009).

As such, we follow Borras et al. (2012, p.405) framing on land grabbing as control grabbing, as follows:

"[C]ontemporary land grabbing is the capturing of control of relatively vast tracts of land and other natural resources through a variety of mechanisms and forms involving large-scale capital that often shifts resource use to that of extraction, whether for international or domestic purposes, as capital's response to the convergence of food, energy and financial crises, climate change mitigation imperatives and demands for resources from newer hubs of global capital.”

An accompanying contest can be observed at the level of governance, which is about authority and control of institutions. Land grabbing is making it evident that contests over governance are not limited to the institutions that facilitate specific land deals but in fact are much more expansive and cut across a variety of institutions and practices that go beyond the land registries and the state and extended to transnational actors and global institutions. A distinction we make here with regard to existing work is that the control and authority over land is increasingly deterritorialized by the process of land grabbing. This involves the formal transfer of control to foreign interests, and the increasing interaction among the 
production practices on the land with other international and transnational governance practices, such as investment, trade and certification regimes. The latter in turn shape what is produced, how it is produced and how production moves across borders. Such a diffused concept of authority does not necessarily override national land authority, since states can terminate a lease or sale, however, the fact remains that land control and authority is entangled across various types of governance institutions at multiple scales of which the national is only one part.

The thickening web of governance institutions relevant to a specific land grab will vary considerably, depending on the type of modality of acquisition, commodity type, production process, and final market destination. Two general and interrelated features can be deduced. The first is that the contestation over authority is likely to be more crowded. Investors, states, domestic and global civil society, and transnational, international and regional institutions are likely to be involved in contesting land control and authority. The second feature is that these contests go beyond the authority over particular pieces of property. The nascent transnational politics of land grabbing point to a more generalized contest over the rules of the global resource accumulation game. However, it is not just rules that are jockeyed over by actors. Control over the norms, discourses and institutions, as well as specific rules of particular regimes are also being contested. The targeting of global and transnational policy spaces (e.g., FAO, G8/G20, and CFS) by actors positioned across the pro- and anti-land grabbing continuum (see Borras, Franco and Wang, 2013, this volume) illustrate that conflicts over land can occur at vast distances from the land as well as on the spot. It also confirms that such contests over governance and authority at different scales span a range of formal and informal modes of governance. This goes beyond the specific provisions in the Voluntary Guidelines or the World Bank Principles of Responsible Agricultural Investment but a much broader contest over what the global agenda on land grabbing should be about, what the guiding norms and principles should be, the production of legitimating and delegitimizing discourses and framing which provide the context and meaning for specific rules and governance practices.

Control grabbing and land authority are dialectically linked: one cannot happen without the other. For examples, investors cannot make land deals without constant use of international institutions and rules; contemporary land grabbing works through, not against, international and bilateral investment, trade, and development regimes (Sassen, 2013, this volume; McMichael, 2013, this volume; Künnemann and Monsalve Suárez, 2013, this volume). Control grabbing and land authority also make it clear that such transnational contests feature highly asymmetric power relations because some actors are endowed with differentiated levels to create and control governance for land. For example, investors can leverage massive financial resources to acquire land at very favourable terms, can hire the best investment lawyers to draw up contracts that shift the risks on to host states and local peoples, and can hire lobbyists and experts to play global rules to their favour, and so on.

The approach to the study of land grabbing and governance offered in this collection takes complexity and indeterminacy as a given. In particular, we recognize that the contestation of specific land deals and local institutions and practices are more likely to be entangled with one another in a more direct way, the overlap of actors much tighter, and developments of such contests to move much more in parallel at the local/national level. Shifting our gaze to the global level, including the manifest global-local interactions and dynamics, means not only that localized land grabs and struggles over global governance are distanced but that the actors will be highly diverse and not necessarily networked or occupy the same global policy spaces. Moreover, global-scale developments are perhaps less likely to move in parallel or interact as directly with events on the ground due to the specific challenges of contesting global governance, including the distance between global rule-making and implementation on the ground, the general underdevelopment of global-local measures to enforce accountability, and the challenge of 
ensuring cooperation and coordination among highly diverse actors and interests at multiple-scales without a centralizing authority. However, these aforementioned challenges are general to other fields of global governance, many of which have been overcome. As such, it is important to remind ourselves that what is in fact occurring through contestation at the local and global levels is the production of new forms of global land governance. This process is highly fluid and the interaction between the local and the global, and the multi-layered and multi-site contests for control of land and institutions is a key dynamic that is shaping this new field of governance. The novel development is that whereas land contests were more or less understood as localized, these contests are now becoming globalized/globalizing and taking place in a much more congested multi-scale terrain of multiple actors, institutions and frameworks. To sum up, the global land grab is as much about controlling governing institutions as it is about controlling resources. . Governance provides a useful additional entry point that brings into focus the contest that is occurring by a myriad of actors to seek control and influence over the institutions that govern land.

\section{The Evolving Terrain of Study}

In addition to the themes discussed above there are developments specific to emerging global land governance that warrant further attention and discussion. These including the complexity of governing land grabbing; terminology and discursive debates; and, the politics of numbers and measurement.

\section{Complexity of Global Land Governance}

The global governance of land grabbing is marked by a high level of complexity. This complexity plays out in several ways. The first is that the phenomenon of land grabbing is itself highly complex and variegated - different types of actors are grabbing land for different reasons in different ways in different countries. As such, there is no 'typical' case of land grabbing (and this is why the concept of control grabbing is a useful conceptualization to organize all this variability). Therefore emergent global land governance at best is targeted to some but not all possible forms of land grabbing. Land is more than a thing (i.e., sovereign territory or a productive economic resource), but inherently multidimensional partly because of its centrality to biophysical and ecological cycles important for human and non-human life. In addition, land has non-material value, for example, when land plays an important role in religious and/or cultural belief systems (see Gentry et al., 2013). The extent to which emergent global land governance can capture the multidimensional character of land is an open question. The peculiar features of 'flex crops and commodities' introduce more complexity from the perspective of potential practices to regulate land grabbing. Flex crops straddle multiple commodity sectors, geographic spaces, and international political economy categories and lead to a blurring of sectoral boundaries and transnational governance mechanisms that "are generally structured by sector or theme, namely, food, feed, energy/fuel, forestry, climate change mitigation strategies” (Borras, Franco and Wang, 2013, this volume). As a result flex crops not only make understanding the global land grab a more difficult challenge but also "fragments the political space and makes single-issue focus advocacy campaigns more difficult” (ibid.).

The issue of complexity in overlapping and/or competing global governance institutions and instruments is manifested also in two other types of control grabbing, namely, green grabbing and water grabbing. Grabbing for environmental ends, or green grabbing, is a phenomenon distinct to the contemporary era of land grabbing as much of it has something to do with climate change. The Reducing Emissions through Deforestation and Forest Degradation (REDD) and its successor regime is a fast expanding global policy that, under certain circumstances, can lead to enclosure and dispossession (Fairhead, Leach 
and Scoones, 2012) as new schemes such as carbon markets and payment for ecosystem services are integrated into land planning, development and livelihood policymaking at the international and national level (Corbera and Schroeder, 2011). Meanwhile, Mehta, Veldwisch and Franco (2012, p.193) argue that on many occasions, land grabbing is essentially 'water grabbing', which they define, broadly as “a situation where powerful actors are able to take control of, or reallocate to their own benefits, water resources already used by local communities or feeding aquatic ecosystems on which their livelihoods are based". In these two types of resource grabbing, global land governance shrinks immediately - and broader lens on governance that incorporates climate change and water governance instruments become necessary. Increasingly, therefore, the challenge is two-fold: deepening and broadening our understanding of global land governance.

Thus far emergent global land governance is highly fluid. Its development to date has been shaped by its being taken up in very specific sites of global governance, namely the FAO and the World Bank. However, there is no reason to assume that these sites, and the frameworks, logics, and politics specific to each will continue to be the primary conduits for the future development and consolidation of global land governance. Margulis and Porter (2013, this volume) argue that emergent global land governance has developed along a pathway where investment and land tenure policy have dominated the global governance agenda to the exclusion of other considerations. Their essay attempts to peel back the layers of this complexity and they examine the variation of across issue areas, the mix of public and private elements, and the mix of local and global elements evident in new global land governance instruments such as the Voluntary Guidelines and the World Bank's PRAI - and the interaction among them. Rather than seeing this complexity as necessarily disabling strategies of resistance by weaker actors to regulate land grabbing, Margulis and Porter (2013, this volume) suggest that "smaller and poorer actors will be most successful working through the types of complexity" and "enrolling transnational actors and networks in efforts to change governance rather than trying to avoid or reverse complexity by focusing more exclusively on solutions at the local level or at the formal intergovernmental level (for instance through treaties)”.

Emergent global land governance may become even more complicated with the appearance of new governance fields on the horizon. In their contributions to this collection, Fortin and Richardson (2013, this volume; see also Goetz, 2013, in this volume), explain that the G8, the World Bank and the corporate agri-food sector favor the inclusion of private standards and certification as part of the global land governance toolbox. International human rights have also gained salience in emergent global land grabbing, not least for the centrality of the right to food in the work of the CFS and in the Voluntary Guidelines. In their contribution to this collection, Rolf Künnemann and Sofía Monsalve Suárez from the Foodfirst Information Action Network (FIAN) suggest that the global land grab may be providing the opportunity for an even bolder human rights approach (see also Claeys andVanloqueren, 2013, this volume). They argue that there is an important historical opportunity to advance the normative and legal basis for operationalizing the human right to land. They cite the recent and successful experience of global civil society efforts in advancing the international human right to food in the 1990s as evidence of the viability of such an approach. Moreover, they stress the international human right to land must build on recent advances in the understanding of human rights as involving obligations not just for states but also for non-state actors, such as transnational corporations, institutional investors and multilateral institutions. This is an obligation to protect, respect and fulfill human rights to fill some of the governance gaps in contemporary international law and post-colonial land regimes that are "impediments to implementing effective redistributive measures in the Global South and provide a framework for policy reforms conducive towards privatizing and commodifying land” (Künnemann and Sofía Monsalve Suárez, 2013, this volume). 
All this suggests potential further crowding of emergent global land governance. Such crowding is likely to intensify the already significant asymmetries of power among states, between investors and local peoples, and between states, investors and global civil society. As such, a strategy for containing or managing emergent global land governance may be desirable. The Künnemann and Monsalve Suárez (2013, this volume) proposal for the human right to land is a potential organizing principle to address evolving global land governance. However, it is likely that this will be resisted by states and also some civil society actors that see this regime either as unfavorable to their interests or simply too weak. Nevertheless, this suggests that much norm-building and rule-making on global land governance is likely to take place, and be contested, in the years to come.

\section{Terminology and Discursive Debates}

In addition to getting a general picture of how much land has been grabbed, it is also important to ask questions about how land grabs are being framed and who is doing the framing. Definitions are useful starting points because they permit for greater analytical precision and to the extent it helps simplify for the purpose of research what are very complex processes. At the same time, competing definitions of land grabbing reveal and obscure aspects of the phenomenon, and serve different ends, whether these be academic ends in the sense of shaping a scientific field, or political in the sense of advancing certain political projects. The two can be intertwined.

This tension is most evident in deciding what term to use to label this phenomenon. The use of the term 'large-scale land acquisition' is the most commonly used descriptor. Other commonly used terms in the literature and public discourse include cropland expansion, land grabs, land deals, and the global land rush, to name a few. Each term plays a discursive role. Despite efforts by many actors to present largescale land acquisitions as a 'descriptive' label, it is important to acknowledge that this term is not a neutral one. The word 'acquire' makes reference only to the actions of those acquiring land and evokes administrative transaction between those who seek to acquire land and those who give up land. This particular semantic frame can render invisible the existence of, and consequences, for land users, who may not be the party giving up land. The term 'acquisition' is a technical, administrative term. In a lot of ways, wittingly or unwittingly, it depoliticizes contemporary land grabbing. Therefore the term acquisition is part of a legitimizing discourse. This term is especially popular among key policy and governmental actors. This is the term preferred by the World Bank, (inter)governmental institutions, as well as by the International Land Coalition (ILC), which is a coalition of the international financial institutions (World Bank, IFAD), intergovernmental institutions (e.g. FAO), aid donors and some NGOs (e.g. Oxfam). By comparison, the term land grab evokes something very different. A "grab", like a "power grab", suggests an unfair appropriation of something and this is a cogent reminder of the normative power of discourse and framing. More generally, the term land grabs evokes the legacy of colonialism and imperialism. The term 'land grabbing' politicizes and historicizes contemporary land grabs. We consciously use the terms land grabs and land grabbing in this collection to remind us that these actions often occur under conditions of highly asymmetric power relations, access to information, and distribution of benefits and costs, and are often linked back to historical legacies of exclusion and dispossession.

\section{Counting land grabs and the politics of numbers/measurement}

The situation facing anyone engaged in the global land grabbing debate is a lack of sufficient empirical data. While this may be factually true, it is important to situate the debate about data with regard to the politics of numbers and measurements. Numbers are not objective depictions of reality but implicitly involve political judgements about how phenomenon should be measured and results interpreted (see, 
e.g., Alonso and Starr, 1987; Brysk, 1994). Scholars have recently begun to seriously examine the power of numbers and measurement in global and transnational governance (Hansen and Muhlen-Schulte, 2012; Hansen and Porter, 2012). The importance of international benchmarking, credit-rating and riskmanagement techniques, all of which depend on highly sophisticated measurements and indices, for policy decisions illustrates the fact that the "authority attributed to numerical indicators has enabled various forms of communication and governance at a distance in the global political economy, involving state and non-state actors on different levels” (Hansen and Muhlen-Schulte, 2012, p.456). We observe such politics of numbers and measurement coursing in the policy and academic debates about land grabbing. Numbers play an important role in mediating the creation of land grabbing as a global political and policy issue. We briefly highlight below some of the hotspots of the politics of number/measurement hotspots in the context of land grabbing.

The most publicized and contested numbers are those of the various projects of quantifying the global land grab. After land grabbing came to international attention in 2008 following the publication of GRAIN's 'Seized!' report, there was a rush by international organizations and global civil society to provide figures. At that stage, apart from the knowledge of some specific land deals, there was little publicly available information. The first generation of reports were published between 2008-2010 (e.g., GRAIN, 2008; World Bank, 2009; Von Braun and Meinzen-Dick, 2009; Cotula et al., 2009) with figures on the land acquired varying considerably. Concerns about the accuracy and reliability of the data were frequently cited. Most important, these initial reports had an important symbolic function of ringing the alarm bell: reports communicated to policymakers and publics that land grabs were in fact occurring, land deals were of significant volumes, and that land deals were on a rapid rise across most regions of the world. Thus, the initial reports confirmed land grabbing was a significant global-scale phenomenon and made a strong case for the need for global governance interventions. Once land grabbing was acknowledged as a global problem, a new demand arose for 'better' numbers, especially by states and international organizations reluctant to support the regulation of land grabbing, in order to better inform and guide global policymaking and global civil society actions. This is not at all surprising, since numbers always create demand for more and better numbers.

The political significance of the data, and who produced the data, has become deeply intertwined with the politics of framing and discourse about land grabbing, although these play out in different ways. The fact that land grabbing is a recent development and the state of knowledge about it so limited creates a situation that affords actors engaged in data construction with extraordinary influence in shaping the policy debate. It is important to recall that such data collection practices are a time and resource intensive process, so only a limited set of actors has the capacity to do this. Partly because of the general opacity of land grabbing, no matter how good any data is it will it always be viewed by some as suspect and unreliable. This makes the quantification of land grabbing a catch twenty-two - there is a demand by powerful actors for high quality data in order to have evidence-based policymaking, while at the same time these actors are aware that data may never meet the standards they expect in order to have reliable evidence. Indeterminacy becomes a structural condition as actors continue to muddle forward in creating governance while hoping for precision but simultaneously reading the data with a large grain of salt.

The politics of numbers are also at play in other ways beyond the quantification of the land grabbing. The World Bank has deployed two sets of measure to explain the incidence and location of land grabbing. The Bank has argued that land grabbing is happening in countries with weak governance. Citing multiple examples of questionable land deals in Sub-Saharan Africa, the Bank suggests there is a correlation between undesirable land investments and states where institutions and the rule of law are weak (even though a lot of land grabbing occurs where states are 'strong' such as in Brazil and 
Australia). To make such a claim the Bank is directly referring its own Worldwide Governance Indicators. These indicators face considerable criticism for their accuracy and political bias (Thomas, 2010; Langebin and Knack, 2009, Arndt, 2008; on power/knowledge see Löwenheim, 2008). However, for policymakers engaged in global land governance, this is a mere footnote because the Bank's expert authority (and the reverence of G8 and many G20 officials for the World Bank's data producing prowess) ensure its arguments are heard loud and clear. This also works to confirm many policymakers' pre-existing assumptions and biases because of many of them share the World Bank's vision of agricultural-led development. This marshalling of the evidence presents a particular policy problem that suggests land grabbing per se is not the problem but weak governance at the national level. It also partly suggests that solutions to the problem need to be directed at beefing up national institutions rather than cross border regulation.

In short, there is a major push in global policy circles to produce more credible data. While better figures would certainly be welcome, it is important for scholars to contextualize this exercise as primarily a political one. Ultimately, the differences in quantification methods are rooted in the competing definitions of and political positions on regulating land grabbing.

\section{Conclusion}

The contemporary wave of land grabbing is a unique world historical event that reveals a nascent shift in the global political economy towards a more polycentric configuration of power and production. What appears on the surface to be rational responses by states and firms to outsource agricultural production in a context of rising prices and uncertainty about supply is in fact much more. The essays in this collection situate land grabbing as symptomatic (and amplifying) of deeper structural changes that feature the simultaneously the de-territorialization and commodification of sovereign national territory across much of the globe, and the partial geographical relocation of global agricultural production that includes significant change in what is grown, for what ends, and for whom. These changes are produced (and reproduced) by the emergence of new centers of power and capital that extend beyond the North to include emerging powers such as China and Brazil as well as less mighty but highly significant ones such as Vietnam, Argentina, South Korea and the Gulf States. This polycentric order is also evident in the multi-directionality of contemporary land grabbing by states and firms that travel in North-South, South-North, North-North and South-South directions. The massive shifts in power and production that are driving contemporary land grabbing are thus far flowing through the architecture of advanced neoliberal globalization. Whereas contemporary land grabbing is driven by diverging logics, such as the commodification of land and/or 'security mercantilism' that may have illiberal ends, today's grabs are facilitated by the institutions and practices of neoliberal globalization (i.e., liberalized international investment, finance, and trade regimes, and going forward with sustainability regimes).

The global land grab has catalyzed emergent global land governance. This is an extraordinary development in the historical trajectory and practice of land politics and governance with the explicit reframing of land as a governance issue at the global-scale. As a result, land governance practices are being reconfigured to recognize and address the interaction between localized and transnational forms of authority. This, of course, has long been a social reality and lived experience for those living on the land even if earlier global governance did not always reflect this reality. The most concrete element of emergent global land governance is the new Voluntary Guidelines on land tenure that articulate this global/local nexus. However, by no means do the Voluntary Guidelines capture the full spectrum and diversity of actors, institutions and practices active and relevant to land. Instead, the Voluntary 
Guidelines need to be contextualized as the first but not necessarily final word on global land governance.

It is remarkable that land grabbing is prompting contestation largely within the global governance institutions rather than outside them. "Global” issues often have a slow journey of being transformed from local problems to ones of universal relevance. The contestation of land grabbing was immediately recognized as a global-scale challenge. This reading was evident with the G8/G20 inclusion of land grabbing as an issue of global relevance and emphasis placed on land grabbing during the negotiating of the Voluntary Guidelines in the CFS. As a result, there has been a fairly rapid consensus for global rulemaking projects on land (even if there are competing views on the objectives and goals of such projects). The changing terrain of the contestation of land grabbing at the global-scale are notable with radical transnational social movements being present and active in global governance of land grabbing from the get-go. Even if one acknowledges that the CFS is only one of the relevant institutions in emerging global land governance, and its authority to make binding rules may be very limited, the manner in which the CFS has taken on the status of a central institution for global deliberation on land governance and the openness of its policy space to social movements are remarkable. This is now acknowledged by the increasing presence of and serious engagement by powerful actors - states and increasingly the private sector alike. It may be too early to claim the long-term significance of the CFS is for 'democratizing' global governance but the content of its work programme does suggest that it is unlikely to be a body that will simply rubber stamp the preferences of the most powerful actors. Thus, the CFS's work on land grabbing is likely to contribute to making highly visible and public the political contests for control over land and authority over institutions. It may prove fertile ground for novel experiments to enhance the quality of deliberation, transparency and legitimacy of global governance around a highly dynamic and explosive issue within a significantly inclusive and diverse setting of actors holding a wide spectrum of political ideologies and goals. In the end, the impact of its global policy decisions will depend in large part on the degree to which they constitute reference points for social movement mobilization and are brought to bear on policies and legislation at national level, an object for future research.

Contemporary global land governance is at an embryonic phase with its future contours not yet discernable. Whereas the Voluntary Guidelines may provide the foundations for a progressive transnational framework to land tenure and rights there is no reason to assume that future global land governance will develop along these lines. Given the broad shifts in power and production in the global political economy, and the rising tensions this is producing in other areas of global governance such as the WTO and UN climate change talks, we should not necessarily expect global land governance to continue to develop smoothly or in the same manner or form as previous global rule-making projects in other fields. What is clear is that the dynamics of contestation will be important in shaping future global land governance. We expect that future outcomes may be highly determined by the degree to which contestation of global land governance comes to grips with the complexity of land grabbing.

First, our reading is that the prominence of 'flex crops and commodities' in the global land grab suggests that public/private crop-specific sustainability/certification regimes and single-issue transnational advocacy campaigns are insufficient strategies. Yet it is recognized that sustainability/certification schemes are presently de rigueur in contemporary governance and such instruments and practices continue to have significant support among many powerful and influential actors across states, the private sector, global civil society and international organizations. As such, how the contestation of land grabbing can shift the terrain of debate beyond sustainability/certification schemes (or not) will be a critical juncture in the development of global land governance. We expect such political struggles will be 
galvanized in the upcoming transnational negotiations over responsible agricultural investment in the CFS.

Second, the contestation for control of institutions may not likely remain confined to the present focal points of global political interactions, that is, the CFS (and the FAO where global social movements are most included). As several of the contribution to the collections emphasize, land grabbing encompasses a much broader form of dispossession than access to land - it is deeply tied to financialization of the global economy, changing national policies and patterns of world trade, and to ecological crises, all of which themselves manifest as domains of contested global governance. Therefore, we suspect that the broadening and deepening of global land governance beyond its present agriculture and food security anchoring is inevitable in the future. This suggests to us that even more difficulties will present themselves in the future because there is no framing that would be broadly accepted by all actors to bridge these multiple contested domains.

\section{Acknowledgements}

We would like to express our appreciation to Barry Gills for his encouragement and support to pursue this project. We thank the authors for committing and contributing their ideas and time to produce the original essays in this collection. We also wish to recognize the efforts of all the peer reviewers who contributed invaluable feedback that strengthened the quality of this collection.

\section{References}

Alden-Wily (2012) Looking back to see forward: The legal niceties of land theft in land rushes, Journal of Peasant Studies, 39(3-4), pp. 751-775.

Allan, J.A., Keulertz, M., Sojamo, S. \& Warner, J. (2012) Handbook of Land and Water Grabs in Africa: Foreign Direct Investment and Food and Water Security (Milon Park \& New York: Routledge).

Alonso, W. \& Starr, P. (1987) The Politics of Numbers (New York: Russell Sage Foundation)

Araghi, F. \& Karides, M. (2012) Land dispossession and global crisis: Introduction to the special section on land rights in the world-system, Journal of World-Systems Research, 18(1), pp. 1-5.

Arndt, C. (2008) The politics of governance ratings, International Public Management Journal, 11 (3), pp. 275-297.

Brand, U. (2005). Order and regulation: Global governance as a hegemonic discourse of international politics?, Review of International Political Economy, 12(1), pp. 155-176.

Borras, S.M., Franco, J.C. \& Wang, C. (2013) The Challenge of Global Governance of Land Grabbing: Changing International Agricultural Context and Competing Political Views and Strategies, Globalizations, 10(1).

Borras, S.M., Gomez, S., Kay, C. \& Wilkinson, J. (2013) Land grabbing and global capitalist accumulation: Key features in Latin America, Canadian Journal of Development Studies, 33(4), pp. 216. 
Borras, S.M., Franco, J.C., Gomez, S., Kay, C. \& Spoor, M (2012) Land grabbing in Latin America and the Caribbean, Journal of Peasant Studies, 39(3-4), pp. 845-872.

Borras, S.M. \& Franco, J.C. (2011) Political dynamics of land grabbing in Southeast Asia:

Understanding Europe’s role, Discussion Paper, (Amsterdam: Transnational Institute).

Borras, S.M \& Franco, J.C. (2010) From threat to opportunity? Problems with the idea of a 'Code of Conduct’ for land grabbing, Yale Human Rights \& Development Law Journal, 13(1), pp. 507-523.

Borras, S.M. \& Franco, J.C. (2009). Transnational Agrarian Movements Struggling for Land and Citizenship Rights. IDS Working Paper 323, pp. 1-44 (Brighton: Institute for Development Studies).

Braithwaite, J. \& Drahos, P. (2000) Global Business Regulation (Cambridge: Cambridge University Press).

Brysk, A. (1994) The politics of measurement: The contested count of the disappeared in Argentina, Human Rights Quarterly, 16(4), pp. 676-692.

Cashore, B. (2002) Legitimacy and the privatization of environmental governance: How non-state market-driven (NSMD) governance systems gain rule-making authority, Governance, 15(4), pp. 503529.

Claeys, P. \& Vanloqueren, G.(2013) The Minimum Human Rights Principles Applicable to Large-Scale Land Acquisitions or Leases, Globalizations, 10(1).

Clapp, J. (1998) The privatization of global environmental governance: ISO 14000 and the developing world, Global Governance, 4(3), pp. 295-316.

Clapp, J. \& Fuchs, D.A. (2009) Corporate Power in Global Agrifood Governance (Cambridge:

Massachusetts Institute of Technology Press).

Cotula, L. (2012) The international political economy of the global land rush: A critical appraisal of trends, scale, geography and drivers. Journal of Peasant Studies, 39(3\&4), pp. 649-680.

Corbera, E. \& H. Schroeder, H. (2011) Governing and implementing REDD+, Environmental Science and Policy, 14(2), pp. 89-99.

Cox, R.W. (1993) Gramsci, hegemony and international relations: an essay in method, in Gill, S.H. (ed.) Gramsci, Historical Materialism and International Relations (Cambridge: Cambridge University Press) pp. 49-67.

Cutler, A.C., Haufler V. \& Porter, T. (1999) Private Authority and International Affairs (Albany: State University of New York Press).

De Schutter, O. (2011) How not to think of land-grabbing: Three critiques of large-scale investments in farmland, Journal of Peasant Studies 38(2), pp. 249-279. 
Deininger, K. (2011) Challenges posed by the new wave of farmland investment, Journal of Peasant Studies, 38(2), pp. 217-247.

Edelman, M. \& Carwil, J. (2011) Peasants’ rights and the UN system: quixotic struggle? Or emancipatory idea whose time has come?, Journal of Peasant Studies, 39(1), pp. 81-108.

Fairhead, J., Leach, M. \& Scoones, I. (2012) Green Grabbing: A New Appropriation of Nature?, Journal of Peasant Studies, 39(2), pp. 237-261.

Fortin, E. \& Richardson, B. (2013) Certification schemes and the governance of land: Enforcing standards or enabling scrutiny? Globalizations, 10(1).

Franck, S. (2009) Development and outcomes of investment treaty arbitration, Harvard International Law Journal, 50(2), pp. 435-459.

Friis, C. \& Reenberg, A. (2010) Land grab in Africa: Emerging land system drivers in a teleconnected world. GLP Report No. 1 (Copenhagen: GLP-IPO).

Galeano, L. (2012). Paraguay and the expansion of the Brazilian and Argentinian agribusiness frontiers, Canadian Journal of Development Studies, 33(4), pp. 458-470.

Gentry, B.S., Sikor, T., Auld, G., Bebbington, A.J., Benjaminsen, T.A., Hunsberger, C.A., Izac, A.M., Margulis, M.E., Plieninger, T., Schroeder, H. \& Upton, C. (2013), Changes in land governance in an urban era, In Seto, K.C. \& Reenberg, A. (Eds.) Rethinking Global Land Use in an Urban Era (Cambridge: MIT Press).

GRAIN. 2008. “Seized! The 2008 Land Grab for Food and Financial Security.” Grain Briefing. Barcelona: GRAIN.

Goetz, G. (2103) Private governance and land grabbing: The Equator Principles and Roundtable on Sustainable Biofuels, Globalizations, 10(1).

Hall, R. B. \& Biersteker, T.J. (2002) The Emergence of Private Authority in Global Governance (Cambridge: Cambridge University Press).

Hansen, H.K. \& Porter, T (2012) What do numbers do in transnational governance? International Political Sociology, 6(4), pp. 409-426.

Hein, W. \& Kohlmorgen, L. (2008) Global health governance conflicts on global social rights, Global Social Policy, 8(1), pp. 80-108.

ICARRD (2006) Final Declaration of the International Conference on Agrarian Reform and Rural Development, Available at: http://www.icarrd.org/news_down/C2006_Decl_en.doc.

Kahler, M. \& Lake, D.A. (eds.) (2003) Governance in a Global Economy: Political Authority in Transition (Princeton: Princeton University Press). 
Künnemann, R. \& Monsalve Suárez, S. (2013) International human rights and governing land grabbing: A view from global civil society, Globalizations, 10(1).

Langbein, L. \& Knack, S. (2009) The Worldwide Governance Indicators: Six, one, or none?, Journal of Development Studies, 46(2), pp. 350-370.

Li, T.M. (2011) 2011. Centering labor in the land grab debate, Journal of Peasant Studies, 38(2), pp.281298.

Löwenheim, O. (2008) Examining the State: a Foucauldian perspective on international 'governance indicators', Third World Quarterly, 29(2), pp. 255-274.

Margulis, M.E. (2013) The regime complex for food security: Implications for the global hunger challenge, Global Governance, 19(1), pp. 53-67.

Margulis, M.E. (2012) Global food security governance: The Committee on World Food Security, Comprehensive Framework for Action and the G8/G20, in Rayfuse, R. \& Weisfelt, N., The Challenge of Food Security: International Policy and Regulatory Frameworks (Cheltenham, UK: Edward Elgar), pp. 231-254.

Margulis, M.E. \& Porter, T. (2013) Governing the global land grab: Multipolarity, ideas and complexity in transnational governance, Globalizations, 10(1).

McKeon, N. (2013) "One does not sell the land upon which the people walk": Land grabbing, rural social movements, and global governance, Globalizations, 10(1).

McKeon, N. (2011) Global Governance for World Food Security: A Scorecard Four Years After the Eruption of the "Food Crisis" (Berlin: Heinrich-Boll-Stiftung).

McKeon, N. (2009) The United Nations and Civil Society: Legitimating Global Governance-Whose Voice? (London: Zed).

McMichael, P.D. (2013) Land grabbing as security mercantilism in international relations, Globalizations, 10(1).

McMichael, P.D. (2012) The land grab and corporate food regime restructuring, Journal of Peasant Studies, 39(3\&4), pp. 681-701.

Mehta, L., van Veldwisch, G. \& Franco, J.C. (2012) Introduction to the special issue: Water grabbing? Focus on the (re)appropriation of finite water resources, Water Alternatives 5(2), pp. 193-207.

Murmis, M. \& Murmis, M.R. ( 2012) Land concentration and foreign land ownership in Argentina in the context of Global Land Grabbing, Canadian Journal of Development Studies, 33(4), pp. 490-508.

Oxfam (2012), Land and power: The growing scandal surrounding the new wave of investments in land, available at: http://www.oxfam.org/sites/www.oxfam.org/files/bp151-land-power-rightsacquisitions220911-en.pdf. 
Peluso, N.L. \& Lund, C. (2011) New frontiers of land control, Journal of Peasant Studies, 38(4), pp. 667-681.

Perrone, N.M (2013) Restrictions on foreign acquisitions of agricultural land in Argentina and Brazil, Globalizations, 10(1).

Ribot, J.C. (1998) Theorizing access: Forest profits along Senegal's Charcoal Commodity Chain, Development and Change, 29 (2), pp. 307-341.

Ribot, J.C. \& Peluso, N.L. (2003) A theory of access, Rural Sociology, 68(2), pp.153-181.

Robertson, B. \& Pinstrup-Andersen, P. (2010) Global land acquisition: Neo-colonialism or development opportunity? Food Security, 2(3), pp. 271-283.

Rosenau, J. N. (1995). Governance in the Twenty-first Century, Global Governance, 1(1), pp. 13-43.

Rosenau, J. N. \& Czempiel, E.O. (eds.) (1992) Governance Without Government: Order and Change in World Politics (Cambridge: Cambridge University Press).

Rosset, P. (2011) Food Sovereignty and alternative paradigms to confront land grabbing and the food and climate crises, Development, 54(1), pp. 21-30.

Sassen, S. (2013) Land grabs today: Feeding the disassembling of national territory, Globalizations, 10(1).

Sassen, S. (2010) A savage sorting of winners and losers: Contemporary versions of primitive accumulation, Globalizations, 7(1-2), pp. 23-50.

Sassen, S. (2006) Territory, Authority, Rights: From Medieval to Global Assemblages (Princeton: Princeton University Press).

Sauer, S. \& Leite Pereira, S. (2012) Agrarian structure, foreign investments on land, and land price in Brazil, Journal of Peasant Studies, 39(3-4), pp. 873-898.

Sell, S. K. (2003). Private power, public law: The globalization of intellectual property rights (Cambridge: Cambridge University Press).

Seufert, P. (2013) Voluntary Guidelines on the Responsible Governance of Tenure of Land, Fisheries and Forests, Globalizations, 10(1).

Sikor, T. \& Lund, C. (2009) Access and property: A question of power and authority, Development and Change, 40(1), pp. 1-22.

Stephens, P. (2013) The Principles for Responsible Agricultural Investment, Globalizations, 10(1).

Thomas, M.A. (2010) What do the Worldwide Governance Indicators measure?, European Journal of Development Research, 22(1), pp. 31-54. 
Urioste, M. (2012) Concentration and 'foreignization' of land in Bolivia, Canadian Journal of Development Studies, 33(4), pp. 439-457.

Visser, O. \& Spoor, M. (2011) Land grabbing in post-Soviet Eurasia: The world's agricultural land reserves at stake, Journal of Peasant Studies, 38(2), pp. 299-323.

Von Braun, J. \& Meinzen-Dick, R. (2009) ‘Land Grabbing’ by Foreign Investors in Developing Countries: Risks and Opportunities, IFPRI Policy Brief 13, (Washington DC: International Food Political Research Institute).

Weiss, T.G.(2000). Governance, good governance and global governance: Conceptual and actual challenges, Third World Quarterly, 21(5), pp. 795-814.

Wilkinson, J., Reydon, B. \& di Sabbato, A. (2012) Concentration and foreign ownership of land in Brazil in the context of global land grabbing phenomenon, Canadian Journal of Development Studies, 33(4), pp. 417-438.

Wilkinson, R. \& Hughes, S. (2002). Global Governance: Critical Perspectives (New York: Routledge).

White, B., Borras, S.M, Hall, R., Scoones, I. \& Wolford, W. (2012) The new enclosures: critical perspectives on corporate land deals, Journal of Peasant Studies, 39(3\&4): 619-647.

Woertz, E. (2013) The governance of Gulf Agro-investments, Globalizations, 10(1).

Wolford, W., Borras, S.M., Hall, R., Scoones, I., \& White, B. (2013). Governing global land deals: The role of the state in the rush for land, Development and Change, March 2013.

Woodhouse, P. (2012), New investment, old challenges: land deals and the water constraint in African agriculture, Journal of Peasant Studies, 39(3\&4): 777-794.

World Bank (2010) Rising Global Interest in Farmland: Can it yield sustainable and equitable results? (Washington DC: World Bank).

Zoomers, A. (2010) Globalisation and the foreignisation of space: Seven processes driving the current land grab, Journal of Peasant Studies, 37(2), pp. 429-47. 